\title{
WHAT DOES A RENAISSANCE ARISTOTELIAN LOOK LIKE? FROM PETRARCH TO GALILEI
}

\author{
Marco Sgarbi
}

A pervasive and much cherished paradigm among historians of science is to view the origin of "modern science" as a reaction against Aristotelians and Aristotle's ruling authority. But what does a Renaissance Aristotelian really look like? This article seeks to answer this question by bringing to light direct accounts of what it meant to be an Aristotelian at that time and by showing a connection between the antiauthoritarian stance that is typical of early modern scientists and thinkers and that of certain Renaissance Aristotelians.

\section{Renaissance Aristotelianisms}

In his pioneering Aristotle and the Renaissance, Charles B. Schmitt (1983) supports two main theses. The first says that in the Renaissance, it is impossible to identify a single, continuous, coherent, and cohesive Aristotelian tradition. Rather, it would be better to speak of a multiplicity of Aristotelianisms (1033). The second thesis, no less important, maintains that in the Renaissance, Aristotelianism became more and more eclectic, its contours more and more confused, almost to the point of losing its specificity while incorporating the doctrines, ideas, and theories of other philosophical traditions (89-109). Scholars often support either the first or the second thesis, sometimes both, but rarely

\footnotetext{
Contact Marco Sgarbi at the Università Ca’ Foscari, Venezia Dorsoduro 3246, 30123 Venezia, Italy (marco.sgarbi@unive.it).

I gratefully acknowledge the help of Alessio Cotugno, Chris S. Celenza, and Laura Refe during the writing of this article. This research was made possible thanks to the ERC (European Research Council) Starting Grant 2013, no. 335949, "Aristotle in the Italian Vernacular: Rethinking Renaissance and Early-Modern Intellectual History (c. 1400-c. 1650),” http://aristotleinthevernacular.org. Unless otherwise stated, all translations are mine.
}

HOPOS: The Journal of the International Society for the History of Philosophy of Science, vol. 7 (Fall 2017). 2152-5188/2017/0702-0003\$10.00. () 2017 by the International Society for the History of Philosophy of Science. All rights reserved. Electronically published September 11, 2017. 
have the two been considered conjointly, as this leads to the conclusion that there existed multiple, eclectic Aristotelianisms.

The use of the adjective "eclectic" complicates the classification of Aristotelianism, which becomes a somewhat fluid movement that is in continuous transformation. If we think of this eclecticism in conjunction with the fact that there is not only one Aristotelianism but many kinds, the entities that one should define are so evanescent that their characterization is limited to a single case that in fact renders the category of "Aristotelianism" itself impossible to use, even for instrumental or historiographical purposes. Dealing with either pure Aristotelianism or vernacular Aristotelianism, or with any other kind of Aristotelianism for that matter, can provide a very first general and generic orientation on the subject, but the concept of "Aristotelianism" remains so indistinct that in the end, the crucial question is what Aristotelianism is in any given case-a question that is almost always embarrassing, if not in fact impossible, to answer.

Edward Grant (1987) tackled this problem very directly in his seminal paper "Ways to Interpret the Terms 'Aristotelian' and 'Aristotelianism' in Medieval and Renaissance Natural Philosophy." If at first glance one could support in a narrow sense the idea that an Aristotelian is someone who assumes the truth of all that Aristotle said, in the end, Grant argues, we will find that no philosopher of that time accepted the Stagirite's ideas and convictions completely, and we should admit that what is most interesting about Aristotelianism "is the considerable variety of opinion amongst Aristotelians on a rather wide range of topics" (338). The terms "Aristotelianism" and "Aristotelian" appear, as we have said, "to lack reasonably precise defining characteristics" (342). Grant thus advances two possible positions for establishing the criteria that have to be met for one to be considered an Aristotelian. The first position establishes that "Aristotelianism is constituted not of Aristotelians but rather of an aggregate of ideas" (346). However, he admits the impossibility of establishing consistent criteria "for deciding which ideas would qualify for the deviant cluster around the essential core of Aristotle's concepts" (346).

The second position is based on the assumption that no two Aristotelians agreed in all of their conclusions, and so every Aristotelian could be conceived of as an independent version of Aristotelianism, so much so that "there are as many Aristotelianisms as there were individual Aristotelian" philosophers (Grant 1987, 348). In this sense, it is quite clear that there is no need for a characterization of Aristotelianism and no need to identify departures or anomalies, since "there are only individual Aristotelians who produce individual Aristotelianisms each of which consists of an array of ideas, principles, and interpretations" (348). Grant favors this second position even if he is aware of the possible inclusion in the Aristotelian tradition "of ideas that are antithetical to the views 
of Aristotle and to those of most Aristotelians," such as in the case of the Aristotelian Thomas White, who believed in the heliocentric theory (350).

Already, Paul O. Kristeller $(1961,31)$ warned that Aristotelianism was not characterized "by a common system of ideas" but by "a common source material, a common terminology, a common set of definitions and problems, and a common method of discussing these problems." J. M. M. Hans Thijssen (1991) saw in the institutional setting the key element to understanding the continuity and transformation of the Aristotelian tradition. Indeed, all Aristotelian "arguments, debates and conflicts, the whole proliferation of theories, occur within a very general and large body of assumptions that are of many varieties" and that concern "terminology, senses, standards of arguments, principles, and source material." In other words, without this shared vision of the world, alleged Aristotelians "would not be able to communicate at all" (510). In Thijssen's view, Aristotelianism should be conceived as "a particular research programme that typically consists of a 'hard core,' which is not under dispute, a 'protective belt' of hypotheses that get adjusted and readjusted to defend the core, and a heuristic, which includes a set of problem-solving techniques" (511). The hard core of Aristotelianism would consist of most general propositions and principles such as that "the forms are the determinants of being, that the sublunary world is constituted of four basic elements, or that reality should be interpreted in terms of the relationship between act and potency" (511). This core would represent sufficient criteria to establish whether an author is Aristotelian. However, this approach does not answer to Grant's case of White, who himself professed to be an Aristotelian but defended heliocentrism against geocentrism, undermining the "hard core" of the Aristotelian research program (Grant 1987, 350).

In this article I propose a more prudent way of tackling the problem, which is to leave aside for the moment the meaning of the concept of "Aristotelianism" and the "hard core" of the Aristotelian tradition and look for direct evidence of what it meant to be an "Aristotelian" in the Renaissance, by focusing on self-professions and definitions. Having established the correct definition of "Aristotelian" at that time, it then becomes possible to proceed with the characterization of Aristotelianism. Of course, any definition based solely on the direct statements of those who declared themselves Aristotelian may make the characterization of Aristotelianism seem rather narrow. The historiography would also include those who did not openly profess themselves to be "Aristotelians" as such or who supported ideas close to Aristotelianism. Most Aristotelians of the time had no reason to openly profess their adherence to Aristotelianism anyway, since Aristotelianism was the predominant philosophy in 
the universities. As narrow as this definition may seem, however, it is nevertheless a truthful and definite image of what Aristotelianism was in the Renaissance.

\section{Petrarch and Other Humanists}

Petrarch, the father and founder of humanism, provides one of the first connotations of what it meant to be "Aristotelian." He is best known for his invectives against physicians, Averroists, Scholastics, and Aristotelians, but in his critical remarks he proceeds with subtle distinctions that allow us to appreciate what an Aristotelian actually was. His most significant invective, On his own ignorance (De suis ipsium et multorum ignorantia), targets four Aristotelians: Leonardo Dandolo, Tommaso Talenti, Zaccaria Contarini, and Guido from Bagnolo, charging them with ignorance, illiteracy, and idiocy —in other words, with being men without a classical education. As unpromising as it may seem at first blush to resort to one of the very first anti-Aristotelian writings par excellence for a definition of an Aristotelian, in criticizing these alleged Aristotelians Petrarch in fact paints a clear picture of what it really meant to be a follower of Aristotle, and in so doing Petrarch clearly establishes that his anti-Aristotelianism is not so much against Aristotle and his doctrines as against these alleged Aristotelians, in opposition to whom Petrarch sets the true meaning of being Peripatetic.

Petrarch $(2003,11)$ adjures these four doctors to leave the path of the sweet and pleasant Aristotle and desist from transforming his philosophy and language into the rough and scabrous babbling of philosophasters. His criticism was based on the conviction that for Aristotle eloquence was the first ornament of philosophy (11). It is a charge that all humanists after Petrarch attribute to Aristotelians and in particular to university philosophers, who employed a technical lexis and a syntax devoid of any rhetoric (11).

Petrarch's is a diatribe against philosophasters who claim to follow the authority of Aristotle but delight in beguiling ignorant minds with the magic of his name alone (Petrarca 2003, 11). These alleged philosophers call themselves wise men and Aristotelians, but for Petrarch (1992) they are "ignorant or demented, like an army of black ants swarming forth from the entrails of some rotten oak" (Seniles, XII, 2). They can do nothing but appeal to the authority of Aristotle's words without even understanding the concepts of his philosophy. They have no real philosophical knowledge, only sterile erudition. These alleged Peripatetic philosophers have no grasp of Aristotle's thought because they surmise that the Stagirite had resolved all philosophical problems within linguistic and dialectic debate (Garin 1969). "They called themselves Aristotelians because also Aristotle argued," but they did not understand that for him 
dialectic was only a part, a means, and never an end: "pars matutina, non serotina" (Petrarca 1975, Familiares, I, 7, 7-14; that is the morning and not the evening). Moreover, these conceited Aristotelians were guilty of making false claims about things Aristotle may have said or known. They were content to know his opinion on a given topic without checking whether it was true. The truth came from Aristotle's authority, and anyone who argued against it, such as Petrarch, was a blasphemer. Being philosophers and seekers of the truth meant, for these pseudointellectuals, to be Aristotelians, or more accurately Pythagoreans, "who were only allowed to question whether or not he had said so-where 'he' meant Pythagoras" (Petrarca 2003, 48). Indeed, they were "more the friends of sects than of the truth" (49). Needless to say, Petrarch opposed this characterization of being Aristotelian as being the worshipper of the leader of a sect.

Petrarch $(2003,52)$ continues in this tone, highlighting the ignorance of these Aristotelians who, in his view, are neither philosophers nor Aristotelians because they adore Aristotle without understanding him. Petrarch refuses to bend his knee before Aristotle and is himself accused of ignorance, because the slaves of Aristotle's philosophy consider it a "sacrilege to differ with whatever he said on any subject" (104). In stark opposition to these ignorant philosophasters, "the bright light of the truth overwhelmed Aristotle" (133-34). Similarly, the only interest of the real philosopher should be the truth, not the words or the unverified opinions of other men, as Petrarch's contemporaries believed. Petrarch is methodologically within the Peripatetic tradition, and, in invoking the Aristotelian conception of the Latin saying amicus Plato, sed magis amica veritas, derived from the Nicomachean Ethics (1096 a 15), he proves that his understanding of Aristotle is far greater than that of these alleged Aristotelians. Truth is more important than authority; thus, Petrarch $(2003,113)$ adds,

I have nothing to say against Aristotle, but something to say on behalf of the truth, which I love despite my ignorance. And I have much to say against our foolish Aristotelians. In every single sentence, they daily pound us with Aristotle, whose name alone they grasp, until I suspect that both he and their listeners are disgusted; and they recklessly distort even his most direct statements into twisted meanings. No one loves or reveres men of distinction more than I do. ... Aristotle himself I know to be a great man, but a human one; and I wouldn't say this if I did not know his greatness.

As a human being, Aristotle "could therefore have been ignorant of some things, or even of many things" (Petrarca 2003, 49), but nonetheless Petrarch believes that the Stagirite was "a great man and a polymath" who, with Plato, 
came closest to the truth among the ancient philosophers (103). One should not criticize Aristotle, according to Petrarch, but only his followers. Therefore, one should avoid Aristotle, "not because he committed more errors, but because he has more authority and more followers" (101). Petrarch, in spite of his disagreement with many Aristotelian doctrines, saves the Stagirite from his followers, who exploit him as an authority with uncritical approval. Petrarch knows that one can learn many things from Aristotle's books, but he also knows that "one can learn many things elsewhere too" (113). Thus, Petrarch embodies not only the idea of criticism against authority but also the idea that knowledge is a process that can disprove ancient doctrines while making new discoveries. Such conviction came directly from Aristotle, who did not hesitate to criticize his mentor in order to bring the truth to light: the true Aristotelian is the follower of the truth, not of some authority.

Petrarch's conception became popular among humanists such as Coluccio Salutati, Leonardo Bruni, and Lorenzo Valla, who intensified the criticism against these alleged Aristotelians. ${ }^{1}$ Thus in the quattrocento, as Paul O. Kristeller (1961) has rightly shown, two apparently opposed cultures, that of the humanists and that of the Aristotelians, came into contact with each other. Among the Aristotelians one can count Averroists, Thomists, Scotists, and other Scholastic sects. But also, more generally, and of course with some exceptions, all university professors, who were obliged by statute to teach Aristotelian doctrines. The authority of Aristotle was thus twofold: on the one hand, it was characterized by the undisputed acceptance of the truth of his ideas, and on the other it was the result of the slavish teaching of his doctrines.

In the Rubrica of his De laboribus Herculis, Coluccio Salutati (1951) launches a deadly attack against the Aristotelians while defending Aristotle's ideas and doctrines, much as Petrarch did. In his eyes, the Aristotelians are philosophers of little value, not dissimilar to common people due to their attachment to authority. They do not deviate from Aristotle's words, which they do not read or understand. Rather than knowing Aristotle's writings philosophically, they are more interested in futile linguistic, philosophical subtleties. Leonardo Bruni, like Salutati, makes a clear distinction between Aristotle and Aristotelians. The Aristotelians presume to teach what they do not know: "If any one should ask them on whose authority and precepts they rely in this splendid wisdom of theirs, they say: the Philosopher's, by which they mean Aristotle's. And when there is need to confirm something or other, they bring forth the sayings in these books which they claim to be Aristotle's - words harsh, awkward, dissonant, which would wear out anyone's ears" (Bruni 1987, 67). And if this were

1. On the humanist reaction against Aristotelians, see Martin's (2014, 28-39) insightful remarks, to which I am indebted. 
not enough, they also affirm that it is impious to contradict Aristotle because "for them ipse dixit has the force of truth, as if he had been the only philosopher, or his sayings were as fixed as those which Pythian Apollo gave forth from his holy sanctuary" (68). Yet Bruni does not aim to criticize Aristotle's thought: "I have no war with that very wise man, only with the folly of these Aristotelians" (68). He wishes only to demolish contemporary Aristotelians while upholding the doctrine of Aristotle's philosophy, which he finds to be true and useful. These Aristotelians are not only ignorant but also filled with "much arrogance," because "they call and esteem themselves wise" and pertly "enrol themselves in Aristotle's family," while "not even in the least thing do I believe they rightly grasp what Aristotle thought" (68). Their ignorance stems from the fact that they do not know the Greek language and rely for their knowledge on unfaithful translations that twist the meaning of Aristotle's words: "It is impossible for them to grasp anything rightly, especially since those books which they say are Aristotle's have suffered such a great transformation that were anyone to bring them to Aristotle himself, he would not recognize them as his own any more than his own dogs recognized Acteon" (69).

Like Petrarch, Bruni emphasized Aristotle's eloquence, which was unknown among the uncouth medieval Aristotelians: "For Cicero says that Aristotle was devoted to eloquence and wrote with an incredible pleasantness. But now we find these books of Aristotle's - if they are even to be considered his-troublesome and harsh to read and entangled in such obscurity that no one except a Sibyl or an Oedipus would understand them" (Bruni 1987, 69). In contrast with these now unreadable writings, according to Bruni, "in Aristotle, all is perfection, indeed, no one was his equal for taking care in composition" (291). To be a real Aristotelian for Bruni meant to follow Aristotle's example as a rhetorician in his ethical and political works, and Bruni devoted most of his life to commenting on and translating works such as the Economics, the Politics, and the Nicomachean Ethics.

Lorenzo Valla takes his criticism even further. Their failings are not just a misplaced devotion to Aristotle, whom they consider "to be like God." Their lack of philological skills and their limited knowledge of the Greek language have restricted their capacity to understand Aristotle's original works and thus the true meaning of his philosophy. Moreover, they disagree with Aristotle's precept to follow the truth instead of the authority. In Valla's (1540, 644) words, these "recent Peripatetics ... have banished the freedom to dissent from Aristotle." They are as those who have never seen the sea but believe they possess the art of navigation. They are "superstitious and foolish and unjust to themselves, because they deny themselves the faculty of searching for the truth" (645). The imperative of philosophical agreement with the authority runs 
counter to the very definition of a philosopher, who is not one who follows other men's opinions but rather pursues truth and virtue according to his own lights. Hence, Valla $(1982,2)$ believes that "the freedom of philosophers, who bravely state what they judge [to be true and virtuous], not only against the leaders of other sects, but against their own leaders, so that they are not bound to any sect, has always existed." Even Aristotle's very first successor, Theophrastus, audaciously dissented from his teacher. Thus, contrary to the recent Aristotelians, one should dissent freely from Aristotle just as Aristotle did from Plato. It is therefore no exaggeration to say that early humanists from Petrarch to Valla adopted an overwhelmingly negative attitude toward the Aristotelians while defending Aristotle as a possible source of truth.

\section{Cremonini and Zabarella}

In the meantime, in the universities there were few discussions about being or not being an Aristotelian. Being Aristotelian was taken for granted and was for the most part required by the university statutes. The debate was rather within the Aristotelian tradition on the question of which was the most coherent interpretation of Aristotle, especially in relation to the Christian religion. Nonetheless, even among the circle of university professors there was a twofold attitude toward Aristotle: to be an Aristotelian meant either to follow Aristotle's undisputed authority or to follow his methodology, which advocated seeking the truth before and beyond the authority.

Key figures in this debate within university Aristotelianism were Cesare Cremonini and Jacopo Zabarella, two leading figures whom Charles B. Schmitt (1983, 10-12) presented as examples of the existence of Aristotelianisms, even in the same place and time. Both spent their lives teaching Aristotelian texts to students at the faculty of arts at the University of Padua but with very different mind-sets.

Cremonini became famous to posterity as the philosopher who refused to look through Galilei's telescope, being content to rely upon Aristotle's words and texts. Following the publication of the Siderius nuncius (1610), Paolo Gualdo writes to Galilei that Cremonini "makes fun of these observations" and keeps repeating that "looking through those glasses confounds his head" (Galilei 1888-1909, 11:165). Cremonini was not interested in Galilei's new discoveries, and he had no intention of responding to his telescopic observations. He considered himself a mere collector and exhibitor of the definitive truth that had already been discovered by Aristotle. Facing the Inquisition, he defended his role as Aristotle's commentator established by the university statutes, stating that "I cannot retract my expositions of Aristotle, since I under- 
stand them in this way, and because I am being paid to expound Aristotle insofar as I understand him, and if I did the opposite, I would be obliged to return the pay. So I will not retract the considerations I have made about the interpretations and refutations that you gave of the explanations because of my honor, the interests of the chair, and therefore of the prince" (Poppi 1993, 105). ${ }^{2}$

The profession of the philosopher, especially an Aristotelian, was nothing more than to comment on and interpret Aristotle's texts. Cremonini was so careful in carrying out his work as Aristotle's interpreter that he even criticized Thomas Aquinas's exegesis, which, in his mind, was not faithful to the Aristotelian text, as it confused philosophy and theology. In Cremonini's eyes, Thomas Aquinas was an excellent theologian but ultimately a bad Aristotelian (Della Torre 1968, 56).

To be an Aristotelian meant for Cremonini to interpret Aristotle's text, and his main concern was to accomplish the task for which he had been hired. One could think that behind this idea Cremonini conceals a distinction between the philosopher, who knows the truth, and the university professor, who is obliged to teach Aristotelian works- but this is not the case. He warns his students to "be aware that the things in which Aristotle moves away from [revealed] Truth are not too many, and that these few things are not clearly demonstrated" (Garin 1994, 376). Thus, Aristotle is the real holder of the truth, and if some passages in his works seem to contrast with this faith, it is only because he did not explain his doctrines sufficiently well.

A clear distinction between the attitude of a philosopher and that of a commentator or a university professor is evident in Zabarella. As Charles B. Schmitt $(1983,11)$ has rightly suggested, the famous Paduan logician emphasizes empirical observation as the basis of scientific cognition and stresses reason, not Aristotle, as the ultimate foundation of science (see also Palmieri 2007). In his works, Zabarella clearly distinguishes the role of the philosopher, or true Aristotelian, from that of the commentator, or false Peripatetic.

In his Praelectio to the academic year 1568, Zabarella explains the duties and limits of the commentator. According to Zabarella, a commentator is one "who transmits to others the knowledge received from another, not as his own, but as the one he received from another" (Milan, Bibl. Ambrosiana, Ms. D 360 Inf., 1v; cf. Bouillon 2009, 461-72). The commentator discovers no new knowledge but merely teaches what he has passively received from other philosophers. In this sense, the commentator is also called an interpreter, because interpretation is "knowledge transmitted as received from another as such." The commentator

2. "Non posso nè voglio retrattare le espositioni d'Aristotile, poichè l'intendo cosi, e son pagato per dichiararlo quanto l'intendo, e nol facendo sarei obligato alla restitutione della mercede. Cosi non voglio retrattare considerationi havute circa l'interpretazione ch'abiate fatte delle lor esplicazioni, cirica l'onor mio, l'interesse della Cattedra, e per tanto del Principe." 
is always inferior to the author on whom he comments because if the commentator held himself to be superior, he would teach "his science rather than that of another" (Ms. D 360 Inf., 2v). The commentator must therefore recognize his inferiority, and for this reason "interpretation involves a certain slavery, and the interpreter [i.e., the commentator] is a servant [interpres servus est]" (Ms. D 360 Inf., 2v). Zabarella criticizes this kind of attitude toward knowledge and maintains that this kind of slavery "is in itself very undesirable" (Ms. D 360 Inf., 3r). The commentator is one who cannot recognize the truth by himself and needs to steal knowledge from the best philosophers. But there is no greater good than to know by oneself (Ms. D 360 Inf., 3r). He who teaches his own knowledge is not a commentator but a doctor, a philosopher in the real sense (Ms. D 360 Inf., 1v). He who looks for the truth instead of the authority can clearly see, according to Zabarella, that many Aristotelian theses must be refuted because they are contrary to reason and faith. So a real philosopher, commenting on Aristotle's texts, should openly admit that some of his ideas are wrong and that he thinks differently (Ms. D 360 Inf., 4r); otherwise, he provides a great disservice to knowledge. In another introductory lecture in 1585, Zabarella makes clear the role of the real philosopher and of the true Aristotelian. A real philosopher is one who investigates science and truth by himself starting from sensation and reason, not from the authority and words of others. According to Zabarella, this is Aristotle's most solid thesis (Dal Pra 1966, 288). Zabarella criticizes those alleged philosophers who pronounce a number of ideas that are "incompatible with sensation and natural reason" (288), without any reference to sensible knowledge. Aristotle "despised neither sensation nor reason, but harmonizing reason to sensation and sensation to reason and relying on the most solid foundations derived from sensation, he sought to penetrate the secret nature of each thing" (289). Zabarella states that one should imitate Aristotle, and he writes that someone is an "imitator of Aristotle and a true Peripatetic because he follows his rule instead of his words" (289-90). The rule is to leave aside probable opinions that do not lead to science in order to concentrate on demonstrative arguments based on sensation. Thus, Zabarella can state that "I will never be satisfied with Aristotle's authority alone to establish something, but I will always rely upon reason; such a thing is truly both intelligent and philosophical for us, and I will also seem to imitate Aristotle in using reason, for in fact he seems never to have put forward a position without using reason" (290). ${ }^{3}$ Equally, Zabarella condemns the attachment of the commentator on Aristotle to his word. One should not be afraid to refute his

3. "Nunquam etiam sola Aristotelis authoritate ad aliquid comprobandum contentus ero, sed rationem semper adhibebo; hoc enim vere ingenium ac philosophicum est et hac quoque ratione videbor Aristotelem imitari, quippe qui nihil unquam sine ratione pronuntiasse videtur." 
opinions or the ideas of other commentators, "quando ratio cogerit" (290; when reason compels). According to Zabarella, therefore, Aristotelian ideas are valid not because they are "Aristotelian" but because after careful scrutiny by the tribunal of reason they are proven to be true.

Two different and competing self-definitions of being Aristotelian circulated in the second half of the sixteenth century. One held that being Aristotelian meant essentially to be a follower of Aristotle's method, namely, an empirical and rational way of finding the truth. The other maintained that being Aristotelian meant to comply with Aristotle's words. Both definitions were positive in the eyes of those who supported them, but things soon changed, especially among the intellectuals outside the university who became interested in Aristotle. As for the humanists, the university professor as a mere commentator on Aristotelian texts came to be viewed as a "retrograde" figure in relation to the progress of knowledge and the advancement of science. These Aristotelians, who did not raise their eyes from the written pages of Aristotle, were the enemy, a conservative force of culture who defended the value of authority over experience, reason, and truth. For all modern thinkers, these were the Aristotelians to attack and criticize. That said, these Aristotelians did not represent the whole of Aristotelianism, and this did not mean to be Aristotelian at that time; rather, it meant to be a university professor who taught Aristotelian doctrines. Obviously, not all professors were averse to accepting the evidence of experience and reason. This is the case with Zabarella, for instance. Pietro Ragnisco $(1885-86,1252)$ was right when he wrote that "it is reasonable to believe that, if [Zabarella] had been a contemporary of Galileo in Padua, he would not have given the unfortunate impression of Paduan philosophy given by his successor," Cesare Cremonini. Some professors, like Zabarella, were more amenable to change, while others, like Cremonini, were more reluctant. In general, however, when the moderns attack Aristotelians, they do not attack Aristotle or his doctrines but the attitude of these alleged Aristotelians in relation to the authority, which is in itself completely anti-Aristotelian. Aristotle himself would have embraced a discussion and revision of his ideas if they were found to be false, simply because amicus Aristoteles, sed magis amica veritas. For this reason, beyond the university cliques, and in the academies in particular, the conception of being Aristotelian in the sense of being a follower of Aristotle's method of finding the truth through experience and reason became popular.

\section{Piccolomini, Bruno, and Galilei}

The symbol of this new way of being Aristotelian was Alessandro Piccolomini. Together with Antonio Brucioli and Bernardo Segni, Piccolomini was one of 
the most active vulgarizers of Aristotle, but at the same time he was an original philosopher who did not hesitate to distance himself from Aristotelian doctrine in order to incorporate elements of Platonism and atomism (Caroti 2003). For Piccolomini, being Aristotelian had a precise meaning. In his Linstrumento della filosofia he wrote, "In order to be more Aristotelian, I shall rely more on unerring sensation, rather than arguments, and I will trust these more than authority: which is as Aristotle himself always does, in the name of reason and sense abandoning all authority, even that of his own teacher" (Piccolomini 1551b, iiiv-iiir). More explicitly, in Della filosofia naturale, he established that "to better imitate Aristotle, I will leave Aristotle, and his reasons which will be no more than likely ... each time the sense shows me the opposite to be true. ... Nor do I believe that I can be deemed any less Aristotelian, this being the authentic Aristotelian way of philosophizing, which in the name of reason and sense will set aside the authority of any philosopher of that time" (Piccolomini 1551a, *iiii[2]v).

If one endorses this conception of being Aristotelian, it is clear that it is possible, for the sake of the truth, to include within Aristotelianism doctrines that are outside the Aristotelian tradition. This conception, however, would ultimately lead not only to an eclectic form of Aristotelianism, as Schmitt wrote, but indeed to the very demise of Aristotelianism as the dominant philosophy in the interpretation of the world. Perhaps this was the destiny of Renaissance Aristotelianism. When being Aristotelian meant to search for the truth instead of authority, its role coincided with that of the philosopher in general, not the follower of a sect. If on the one hand this might appear to constitute the defeat of doctrinal Aristotelianism, on the other it might be understood as the victory of methodological Aristotelianism that infiltrates even the most recent and newest philosophies, especially outside the universities.

This conception of being Aristotelian in the methodological sense was adopted by philosophers such as Giordano Bruno and Galileo Galilei, who are generally considered anti-Aristotelian. ${ }^{4}$ It is hard to determine Piccolomini's influence on Bruno and Galilei, but the proximity of their ideas is striking. ${ }^{5}$

In La cena de le ceneri, Bruno $(2000,34)$ criticizes the Aristotelians for their vain disputes on quibbles and subtleties: "There are many Peripatetics who grow angry, excited, and inflamed on behalf of Aristotle, who want to defend

4. Of course, in their self-declaration of Aristotelianism, a certain degree of eloquence must be recognized. In the assertion of being Aristotelian, one should see the attempt to seize the privilege of calling themselves philosophers, interpreters of truth and nature, as opposed to pedantic university professors.

5. Galilei owned several books by Piccolomini, but apparently neither of the books mentioned in the text-proper was present on his library shelves. Galilei's library catalog, however, is far from being complete and is continuously being updated (see Torrini 2001; Camerota 2011). 
the doctrine of Aristotle, enemies of Aristotle's enemies, who wish to live and die for Aristotle, who do not even understand what is meant by the titles of the books of Aristotle." Like Petrarch and Bruni, he charges these self-styled philosophasters with being ignorant of Aristotelian doctrines: they are "Aristotle's parrots" who twist the sense of his writings to say whatever they want without distinguishing truth from falsehood (95). They are guilty of being unwilling to look for the truth and to not overcome Aristotle's teaching, also in those things that he could not have known. In defending authority, these Aristotelians are like the "bargemen and stevedores of London" (103). Like Petrarch, Bruno compares those who believe only in authority and not in truth, that is, the alleged Aristotelians, to vulgar people. Thus, while Aristotle was a learned philosopher, these "companions of Aristotle . . . are innumerable, imbecile, senseless, stupid, and ignorant persons" (103).

Unlike Petrarch and Bruni (cf. Petrarch, Rerum familiarium, II, 13; Garin 1952, 58), however, Bruno (2000) does not interpret Aristotle as a master of eloquence, and he criticizes those humanists who studied the Stagirite only for the "eloquence and declamatory art" (196). To these humanistic Aristotelians he prefers the cavillatores and the barbarous British philosophers, because "if we have to choose between the two, I set the culture of the mind, however mean it may be, over that of words and phrases, however eloquent" (196). Bruno's standpoint is reminiscent of Sperone Speroni's (1741) ideas in his Dialogo delle lingue and more in general of the rupture of the binomial between res and verba: the real Aristotelians are seekers of the truth of things and not of the eloquence of the words, and in fact "those who are versed in the science of names and phrases but do not worry about things are astride the same ass as that reverend father of asses" (196).

To those who accuse Bruno of subverting and attacking Aristotle and calling him "a donkey," he answers that the Stagirite is an "earth's hero," but he does not wish to believe him "without cause, nor to accept those propositions whose antitheses ... are so compellingly true" (Bruno 2000, 400). Moreover, he adds that "every well-regulated mind and alert judgment" could judge where the truth is, if in the new discoveries or in Aristotle's authority (400). Just as for Piccolomini, for Bruno sensation and reason constitute the privileged ways to truth, also according to Aristotle's teaching.

In the De linfinito, universo e mondi, Bruno $(2000,425)$ resorts to the Aristotelian principle according to which "it were vain and foolish to exercise ourselves to oppose vain and foolish opinions, as our prince of philosophers, $\mathrm{Ar}$ istotle, affirmed." 6 This principle must be applied also to Aristotle's opinions 
"when they are clearly foolish and vain," so much so that it is necessary to "recall to mind the warning of this same Aristotle that, through concentrating regard upon few facts we may sometimes too readily deliver ourselves of opinions; and sometimes an opinion doth command our assent merely by force of custom, whereby that appeared to us necessary which in fact is impossible; or we perceive and learn that to be impossible which is most true and necessary" (425).

As in the case of the humanists, Bruno criticizes the Aristotelians of his time for their obsession with Aristotle's sentences, which are rooted in prejudices hard to eradicate. However, real Aristotelians are those who, in order to judge perfectly, "renounce the habit of belief" and "regard two opposed views as equally possible," dismissing "all prejudice imbibed since birth" (Bruno 2000, 425). Those who do not follow these precepts and are attached only to the authority are false Aristotelians, because "they would not so much exalt Aristotle as manifest their own worthlessness" (425).

In his work, Bruno attacks the Aristotelian doctrines, but his condemnation follows the natural progress of knowledge, to which everyone, including Aristotle, as he himself knew, is subjected. The assault is so powerful and vehement because Bruno's interlocutors are false philosophers who, with the mere pretension of using Aristotle, believe themselves to be wise men. Bruno's criticism is, therefore, primarily an attack against the authority, whatever it is, that aims to overcome the truth.

In his Dialogo sopra $i$ due massimi sistemi del mondo, Galilei characterizes what Aristotelianism is and what Aristotelianism should be, that is, two distinct ways of being Aristotelian in the Renaissance: according to the authority or according to the truth.

The negative stereotype of the Aristotelian of the time is the fictional character Simplicius, the "stout champion and defender of Aristotelian doctrines," whose name recalls both the Greek commentator and a simple and narrow mind and who believes that "to philosophize means nothing more than not to be persuaded by other opinions than those of Aristotle" (Galilei 18881909, 4:571). Simplicius's "greatest obstacle in apprehending the truth seemed to be the reputation he had acquired with his interpretations of Aristotle" (4:31). ${ }^{7}$

7. The secondary literature generally tends to identify Simplicius with the historical figure of Cremonini. There are at least two allusions to Cremonini in the Dialogo where Galilei (1888-1909, 7:94) speaks of "wonderful thoughts of a great professor of Padua" on the heavens. Later in the dialogue Galilei recalls a Peripatetic friend of Simplicius (7:111). Galilei did not want Simplicius to be identified immediately with Cremonini, with whom Galileo still had good relations, and for this reason the Paduan Aristotelian is alluded to only indirectly in the work. Recently, however, Luca Bianchi (2016) has shown how Leandro Pizzoni's praise of Aristotle is strikingly similar to that employed by Galilei when describing the fictional character of Simplicius. 
The Aristotelian is he who believes in Aristotle's authority and in the notion that "the principles of the Peripatetics are such, that one should not fear that with their ruin new sciences could be established" (7:62), because no truth can be found beyond Aristotle's word. Indeed, the "most reverent and most humble slaves of Aristotle" would be likely to deny "all the experiences and observations in the world, and would even refuse to look at them in order not to have to admit them, and they would say that the universe remains just as Aristotle has written; not as nature would have it. For take away the prop of his authority, with what would you have them appear in the field?" (7:348). For these slaves, the only way of being philosophers is to repeat Aristotle's words like parrots. They do not philosophize "with their mind, but merely from having memorized four ill-understood principles," and they are "content to worship the shadows" (7:30). The prevailing attitude of the Aristotelians toward new knowledge is to invoke "mere authority and the bare ipse dixit" (7:134). Thus, Galilei can affirm that it is not an attitude of a real philosopher "to insist, let me say, almost stubbornly in maintaining the manifestly false Peripatetic conclusions . . . as it was a sign of a perfect judgment and noble effect of profound doctrine to defend the falsehood rather than to be persuaded by the truth" (5:235). These Aristotelians aim to "maintain the empire of Aristotle's authority, as it was sufficient for their minor labor and effort to dangerous oppositions" (5:235). This attitude means for Galilei to be neither philosophers nor Aristotelians; in fact, the servile disposition toward authority is contrary to Aristotle's way of philosophizing. Aristotelians were so ignorant that they did not understand that the real power of Aristotle was to base his knowledge on experience and reasoning. ${ }^{8}$ The laziness of these Aristotelians, in Galilei's opinion, harms Aristotle's memory and that of his philosophy. Yet, Galilei has no doubt that "if Aristotle were now alive, he would change his opinion" (7:75).

Against these alleged and self-styled philosophers, Galilei (1888-1909, 18: 248) maintains that he is an "admirer of such a man as Aristotle," and he distances himself from the Aristotelian opinion only when "arguments persuade me to do so, and Aristotle himself taught me to quite down the intellect to what

8. See Galilei (1888-1909, 7:136): "Are you so credulous as not to understand that if Aristotle had been present and heard this doctor who wanted to make him inventor of the telescope, he would have been much angrier with him than with those who laughed at this doctor and his interpretations? Is it possible for you to doubt that if Aristotle should see the new discoveries in the sky he would change his opinions and correct his books and embrace the most sensible doctrines, casting away from himself those people so weak-minded as to be induced to go on abjectly maintaining everything he had ever said? Why, if Aristotle had been such a man as they imagine, he would have been a man of intractable mind, of obstinate spirit, and barbarous soul; a man of tyrannical will who, regarding all others as silly sheep, wished to have his decrees preferred over the senses, experience, and nature itself?" 
persuades reason, and not to the authority of the teacher." In fact, according to Galilei, "Aristotle mocks those who abandon sense experiences to follow a discourse that can be very wrong," that is, he would mock his self-appointed followers (4:179). Because of his high regard for Aristotle, Galilei can write to one of the most important Aristotelians of his time, Fortunio Liceti, that "I believe ... that to be truly Peripatetic, that is an Aristotelian philosopher, one must conform first of all to Aristotle's teachings, proceeding with the methods and with those true suppositions and principles on which scientific reasoning is based, positing the general information which it would be a grave error to depart from" (18:249).

This is for Galilei the true meaning of being Aristotelian, and it is not far from that endorsed by Piccolomini, that is to follow Aristotle's method, in particular that of logic, which directs the mind toward arguing well and finding necessary conclusions. For all these reasons, Galilei (1888-1909, 18:249) says that "I am Peripatetic. ... I am sure that if Aristotle were to return to this world, he would receive me among his followers." Galilei believed that to be a real Aristotelian meant to prefer experience over any argument and argument over any authority, exactly as Piccolomini wrote: "This is also a precept highly esteemed by Aristotle which he placed far in front of the value of all the authority in the world. . . We must not believe in the authority of the others, but we must refute it anytime sensation shows us the opposite of it" (18:249). The alleged Aristotelians are contrary to the "Peripatetic philosophizing" because they consider that "philosophizing well is to receive and support whatsoever saying or proposition written by Aristotle, to whose authority they are subjected, and for the defense of it they induce themselves either to deny sense experience or to give strange interpretations to Aristotle's texts" (18:249). Nothing was more important for Aristotle than the truth, and the discovery of the truth always starts with sense experience.

This conception of being Aristotelian as a lover of truth whose knowledge is based on sensation was quite common in the Galileian context. In the Discorso sopra la stella nuova (1605), written by Astolfo Arnerio Marchiano, who is for some scholars Galilei himself writing under a pseudonym, ${ }^{9}$ we see a similar passage: "Aristotle made his arguments guided by the senses, as he himself confesses; so, if such novelty [the new star] had been seen in his time, or if he were to see it in our time, without error he would change his opinion in order to avoid conflict with his rule about arguments made against sensation; whereas the thing

9. Marialaura Sopplesa $(1974,21-45)$ seems to argue in this direction, but since the paternity of this work is doubtful, we consider it only as a work representative of the Galileian circle. 
is so clear and so manifest that the sciences are true and certain" (Marchiano 1605, A2v). ${ }^{10}$

Another interesting and until now overlooked example is the Dialogo de Cecco di Ronchitti da Bruzene, written by Girolamo Spinelli, prior of Santa Giustina. The dialogue was published in Padua in 1605, but had a second printing some weeks later in Verona (Favaro 1880-81, 210). These two printings present at the end of the dialogue two different versions of the Stanze contro Aristotele. In the Paduan version, the author taunts the foolish Stagirite who believes in the incorruptibility of the heavens and in the fixed stars and who is wrapped in errors because he denies the validity of sensation, demanding more arguments and opposing principles that appear certain. On the contrary, in the Veronese version the author taunts the wise Stagirite, who outrages himself because he does not follow the principles that he gave to himself, that is, to prefer sensation over all arguments and principles $(267,269)$. To be an Aristotelian in this sense means to follow Aristotle's precept to seek the truth starting from sensation.

\section{Conclusion}

Galileo's testimony, if related to that of Piccolomini, who is unanimously considered an Aristotelian, and understood in the context of the anti-Aristotelian criticism inaugurated by Petrarch, allows us to rethink what it meant to be an Aristotelian in the Renaissance.

First of all, an Aristotelian is someone who follows Aristotle. Aristotle, however, can be followed uncritically as an authority. These Aristotelians are usually (at least for the most part), although not always, university professors, whose task was to comment on Aristotle's works.

Aristotle may also be followed in his spirit and method, and an Aristotelian in this sense is someone who looks for the truth through experience and reason, beyond authority. Usually, these Aristotelians worked outside the university context and wrote in the vernacular in order to distance themselves from the doctoral class. These other Aristotelians characterize university professors as

10. This passage finds a parallel in the first day of the Dialogo (Galilei 1888-1909, 7:75): "I declare that we do have in our age new events and observations such that if Aristotle were now alive, I have no doubt he would change his opinion. This is easily inferred from his own manner of philosophizing, for when he writes of considering the heavens inalterable, etc., because no new thing is seen to be generated there or any old one dissolved, he seems implicitly to let us understand that if he had seen any such event he would have reversed his opinion, and properly preferred the sensible experience to natural reason. Unless he had taken the senses into account, he would not have argued immutability from sensible mutations not being seen." On this similarity, see Sopplesa $(1974,30)$. 
false Peripatetics or as nonphilosophers, traitors to Aristotle's message who proclaimed themselves to be the true prosecutors of the Aristotelian tradition.

If we consider Piccolomini's and Galilei's testimonies, the notion of being "Aristotelian" in the Renaissance becomes very wide and includes intellectuals who merely echoed Aristotle's words and thinkers who aimed to find the truth according to the Aristotelian method. The expansion of the notion of being "Aristotelian" carries with it also those of "Aristotelianism" and "Aristotelian tradition," which now include philosophers whom scholars have usually labeled anti-Aristotelian. Obviously, this does not mean that some of these "new" Aristotelians were not critical of Aristotle. It would be anachronistic to think of Galilei as a supporter of Aristotle's ideas, but he did appreciate the Aristotelian method (or style of thinking) nonetheless, even if he and Aristotle endorse quite different scientific methodologies. This means that the criticism of Aristotelianism was against those Aristotelians who betrayed the spirit of Aristotle following only the authority and not the truth. Their anti-Aristotelianism was not necessarily and primarily directed against Aristotle's doctrines; rather, it was against university professors and intellectuals generally who defended the authority as the only source of truth.

The polemical target was thus not Aristotle himself but a conservative philosophy advocated mostly in universities and religious circles. The complexity of being "Aristotelian" in the Renaissance cannot be reduced simply by saying that an Aristotelian was one who supported and defended the validity of Aristotle's ideas or who shared an institutional setting. Paying attention to this broader concept of being Aristotelian can lead to rewriting the history of Renaissance Aristotelianism, including in this narrative authors who are usually excluded from the Aristotelian tradition. Finally, this conception of being Aristotelian may lead to a reconsideration of the end of Aristotelianism, which perhaps did not die with the pedantic, self-styled Aristotelians opposed by Petrarch, Piccolomini, and Galilei but continued with its spirit to influence the greatest modern philosophers.

\section{REFERENCES}

Bianchi, Luca. 2016. “'Hauendo lui publicato sette fogli di carta’: Leandro Pizzoni e la reputazione scientifica di Galileo.” Rivista di storia della filosofia 4:153-74.

Bouillon, Dominique. 2009. Linterprétation de Jacques Zabarella le philosophe. Paris: Garnier. Bruni, Leonardo. 1987. The Humanism of Leonardo Bruni: Selected Texts. Ed. Gordon Griffiths, James Hankins, and David Thompson. Binghamton, NY: Renaissance Society of America.

Bruno, Giordano. 2000. Dialoghi filosofici italiani. Ed. Michele Ciliberto. Milan: Mondadori. 
Camerota, Michele. 2011. "La biblioteca di Galileo: Alcune integrazioni e aggiunte desunte dal carteggio." In Biblioteche filosofiche private in età moderna e contemporanea, ed. Francesca Maria Crasta. Florence: Le Lettere.

Caroti, Stefano. 2003. "L'Aristotele italiano di Alessandro Piccolomini: Un progetto sistematico di filosofia naturale in volgare a metà '500." In Il volgare come lingua di cultura dal Trecento al Cinquecento, 361-402. Florence: Olschki.

Dal Pra, Mario. 1966. "Una oratio programmatica di G. Zabarella, nov. 1585." Rivista critica di storia della filosofia 21:286-90.

Della Torre, Maria Assunta. 1968. Studi su Cesare Cremonini: Cosmologia e logica nel tardo aristotelismo padovano. Padua: Antenore.

Favaro, Antonio. 1880-81. "Galileo Galilei ed il dialogo de Cecco di Ronchitti da Bruzene in prepuosito de la nuova stella." Atti del Reale istituto veneto di scienze, lettere ed arti 7:195-276.

Galilei, Galileo. 1888-1909. Opere. Florence: Barbera.

Garin, Eugenio. 1952. Prosatori latini del Quattrocento. Naples: Ricciardi. - 1969. "La cultura fiorentina nella seconda metà del Trecento e i 'barbari britanni.." In L'età nuova, 139-66. Naples: Morano.

. 1994. History of Italian Philosophy. Amsterdam: Rodopi.

Grant, Edward. 1987. "Ways to Interpret the Terms 'Aristotelian' and 'Aristotelianism' in Medieval and Renaissance Natural Philosophy." History of Science 25:335-58.

Kristeller, Paul Oskar. 1961. Renaissance Thought: The Classic, Scholastic, and Humanist Strains. New York: Harper \& Row.

Marchiano, Astolfo Arnerio. 1605. Discorso sopra la stella nuova. Padua.

Martin, Craig. 2014. Subverting Aristotle. Baltimore: Johns Hopkins University Press.

Palmieri, Paolo. 2007. "Science and Authority in Giacomo Zabarella." History of Science 45:404-27.

Petrarca, Francesco. 1975. Rerum familiarium. Bks. 1-8, ed. and trans. Aldo S. Bernardo. Albany, NY: SUNY.

- 1992. Seniles; or, Rerum senilium. Trans. Saul Levin, Aldo S. Bernardo, and Reta A. Bernardo. Baltimore: Johns Hopkins University Press.

. 2003. Invectives. Ed. and trans. David Marsh and James Hankins. Cambridge, MA: Harvard University Press.

Piccolomini, Alessandro. 1551a. La prima parte della filosofia naturale. Rome: Valgrisi.

—. 1551b. Linstrumento della filosofia. Rome: Valgrisi.

Poppi, Antonino. 1993. Cremonini, Galilei e gli inquisitori del Santo a Padova. Padua: Centro Studi Antoniani.

Ragnisco, Pietro. 1885-86. "La polemica tra Francesco Piccolomini e Giacomo Zabarella nell'Università di Padova.” Atti del Reale istituto veneto di scienze, lettere ed arti 4:121752.

Salutati, Coluccio. 1951. De laboribus Herculis. 2 vols., ed. B. L. Ullman. Turici: In aedibus Theasauri mundi.

Schmitt, Charles B. 1983. Aristotle and the Renaissance. Cambridge, MA: Harvard University Press. 
Sopplesa, Marialaura. 1974. Genesi del metodo galileiano e tramonto dell'aristotelismo nella scuola di Padova. Padua: Antenore.

Speroni, Sperone. 1741. Opere. Vicenza: Occhi.

Thijssen, J. M. M. Hans. 1991. "Some Reflections on Continuity and Transformation of Aristotelianism in Medieval (and Renaissance) Natural Philosophy." Documenti e studi sulla tradizione filosofica medievale 2:503-27.

Torrini, Maurizio. 2001. "La biblioteca di Galileo e dei galileiani." Intersezioni 21:545-58.

Valla, Lorenzo. 1540. Opera Omnia. Basel: Petri.

- 1982. Repastinatio dialectice. Padua: Antenore. 